Article

\title{
Synthesis and Mechanism of Metal-Mediated Polymerization of Phenolic Resins
}

\author{
Zhao Yi ${ }^{1}$, Jizhi Zhang ${ }^{2}$, Shifeng Zhang ${ }^{1}$, Qiang Gao ${ }^{1}$, Jianzhang $\mathrm{Li}^{1, *}$ and Wei Zhang ${ }^{1, *}$ \\ 1 Ministry of Education (MOE) Key Laboratory of Wooden Material Science and Application, \\ Beijing Key Laboratory of Wood Science and Engineering, School of Materials Science and Technology, \\ Beijing Forestry University, Beijing 100083, China; wangw1007@bjfu.edu.cn (Z.Y.); \\ shifeng.zhang@bjfu.edu.cn (S.Z.); gaoqiang@bjfu.edu.cn (Q.G.) \\ 2 Key Laboratory for Liquid-Solid Structural Evolution and Processing of Materials (MOE), \\ School of Materials Science and Engineering, Shandong University, Jinan 250061, China; zjzvip@sdu.edu.cn \\ * Correspondence: lijzh@bjfu.edu.cn (J.L.); zhangwei@bjfu.edu.cn (W.Z.); \\ Tel.: +86-10-6233-8083 (J.L.); +86-10-6233-6912 (W.Z.)
}

Academic Editor: Antonio Pizzi

Received: 4 March 2016; Accepted: 15 April 2016; Published: 26 April 2016

\begin{abstract}
Phenol-formaldehyde (PF) resin is a high performance adhesive, but has not been widely developed due to its slow curing rate and high curing temperature. To accelerate the curing rate and to lower the curing temperature of PF resin, four types of metal-mediated catalysts were employed in the synthesis of PF resin; namely, barium hydroxide $\left(\mathrm{Ba}(\mathrm{OH})_{2}\right)$, sodium carbonate $\left(\mathrm{Na}_{2} \mathrm{CO}_{3}\right)$, lithium hydroxide $(\mathrm{LiOH})$, and zinc acetate $\left(\left(\mathrm{CH}_{3} \mathrm{COO}\right)_{2} \mathrm{Zn}\right)$. The cure-acceleration effects of these catalysts on the properties of PF resins were measured, and the chemical structures of the PF resins accelerated with the catalysts were investigated by using Fourier transform infrared (FT-IR) spectroscopy and quantitative liquid carbon-13 nuclear magnetic resonance $\left({ }^{13} \mathrm{C} N \mathrm{NMR}\right)$. The results showed that the accelerated efficiency of these catalysts to $\mathrm{PF}$ resin could be ordered in the following sequence: $\mathrm{Na}_{2} \mathrm{CO}_{3}>\left(\mathrm{CH}_{3} \mathrm{COO}\right)_{2} \mathrm{Zn}>\mathrm{Ba}(\mathrm{OH})_{2}>\mathrm{LiOH}$. The catalysts $\left(\mathrm{CH}_{3} \mathrm{COO}\right)_{2} \mathrm{Zn}$ and $\mathrm{Na}_{2} \mathrm{CO}_{3}$ increased the reaction activity of the phenol ortho position and the condensation reaction of ortho methylol. The accelerating mechanism of $\left(\mathrm{CH}_{3} \mathrm{COO}\right)_{2} \mathrm{Zn}$ on PF resin is probably different from that of $\mathrm{Na}_{2} \mathrm{CO}_{3}$, which can be confirmed by the differences in the differential thermogravimetric (DTG) curve and thermogravimetric (TG) data. Compared to the $\mathrm{Na}_{2} \mathrm{CO}_{3}$-accelerated PF resin, the $\left(\mathrm{CH}_{3} \mathrm{COO}\right)_{2} \mathrm{Zn}$-accelerated PF resin showed different peaks in the DTG curve and higher weight residues. In the synthesis process, the catalyst $\left(\mathrm{CH}_{3} \mathrm{COO}\right)_{2} \mathrm{Zn}$ may form chelating compounds (containing a metal-ligand bond), which can promote the linkage of formaldehyde to the phenolic hydroxyl ortho position.
\end{abstract}

Keywords: PF resins; metal catalysts; phenol ortho position; synthesis mechanism; ion-polymer

\section{Introduction}

Phenol-formaldehyde (PF) is a high-performance resin that is synthesized by the copolymerization of phenol with formaldehyde. It is widely applied for industrial uses, including adhesives, impregnating resins, and plastics. The excellent properties of PF resin include high mechanical, thermal, and weather stability [1]. However, the lower curing rate and required higher curing temperature compared to other thermosetting adhesives limit the application of PF resins for use in impregnating resins or adhesives [2,3]. Many attempts have been made to accelerate the curing rate or lower the curing temperature, including testing of various catalysts or additives to alter the reaction kinetics, such as carboxylic acid esters [4,5], anhydrides [6], amides [7], carbonate [8], and metallic ions [9]. Additionally, the effects of the condensation condition on the PF resin structure and properties have 
been well studied by conventional analytical techniques. For example, various mechanisms of PF resin hardening accelerated by catalysts or additives have been reported [10]. Some additives, such as sodium carbonate, act solely to accelerate the curing reaction, but other additives, such as propylene carbonate, both accelerate the reaction and also increase the average functionality of the PF reaction system to allow a tighter final network [10]. The properties of basic catalysts, such as the valence and ionic radius of hydrated cations, affected the mechanisms and kinetics of PF resin condensation and, thus, the composition of the final products [9]. Some studies also reported that an alkaline catalyst promoted the formation of dimethylene ethers in the polymerization reaction, and that ortho to ortho $\left(o, o^{\prime}\right)$ ethers were more stable [11]. However, there has been no comprehensive study about the action of catalysts to increase or decrease the ratio of ortho/para reaction position or analysis of the corresponding physicochemical properties of the accelerated PF resins.

The aromatic ring of phenol has ortho and para positions capable of reaction with formaldehyde under certain conditions, but the para position has higher reactivity than the ortho position. The presence of two ortho positions and one para position in an aromatic ring generally could lead to a PF resin containing mostly ortho hydroxymethyl groups [2]. However, in the process of PF resin synthesis, some catalysts could make more formaldehyde or methylol toward phenol ortho positions to increase the ratio of ortho/para substituted positions [12], leading to more reactive functional groups or more unreacted para positions at the curing stage, which may shorten the curing time and increase the cross-linking degree of cured PF resin.

Since metal ions can accelerate the curing of PF resins, we tested the ability of barium hydroxide $\left(\mathrm{Ba}(\mathrm{OH})_{2}\right)$, sodium carbonate $\left(\mathrm{Na}_{2} \mathrm{CO}_{3}\right)$, lithium hydroxide $(\mathrm{LiOH})$, and zinc acetate $\left(\left(\mathrm{CH}_{3} \mathrm{COO}\right)_{2} \mathrm{Zn}\right)$ to decrease curing temperature and accelerate the curing rate of $\mathrm{PF}$ resins. To elucidate the chemical structure of the cure-accelerated PF resins, we performed quantitative liquid ${ }^{13} \mathrm{C}$ NMR to analyze the structural features. Finally, possible synthesis mechanism of metal-mediated polymerization of PF resins was proposed based on the chemical structure analysis and thermogravimetric (DTG) curve.

\section{Materials and Methods}

\subsection{Materials}

Phenol, formaldehyde (37\%), $\mathrm{Ba}(\mathrm{OH})_{2}, \mathrm{Na}_{2} \mathrm{CO}_{3}, \mathrm{LiOH}$, and $\left(\mathrm{CH}_{3} \mathrm{COO}\right)_{2} \mathrm{Zn}$ were obtained from Zhong' an Chemical Industries, Beijing, China and were used directly without further purification, and all other chemicals were AR grade and obtained from Beijing Chemical Industries, Beijing, China.

\subsection{Preparation of PF Resins}

The catalyst-accelerated PF resin was synthesized by batch polymerization with phenol and formaldehyde at a molar ratio of 1:2.2, and the additive amount of catalyst was $6 \%$ based on the total mass of PF resin. In the first step, phenol was mixed in a flask with one third of the formaldehyde and one third of the catalyst. The mixture was quickly heated to $70^{\circ} \mathrm{C}$, and then the heater was turned off. The temperature of the mixture increased to $90{ }^{\circ} \mathrm{C}$ due to the heat produced by polymerization reaction and remained at $93-95{ }^{\circ} \mathrm{C}$ for $1 \mathrm{~h}$. In the second step, the remaining formaldehyde and two thirds of the catalyst were added to the flask and the mixture was heated to $90^{\circ} \mathrm{C}$ and kept at that temperature for $0.5 \mathrm{~h}$. Finally, the mixture was cooled to $40^{\circ} \mathrm{C}$ to yield PF resin. PF resins with different catalysts were synthesized with the same procedure.

\subsection{Preparation of Plywood}

Three-layer plywood $(400 \mathrm{~mm} \times 400 \mathrm{~mm} \times 4.8 \mathrm{~mm})$ was prepared with a single poplar veneer in the middle and two poplar veneers on the top and bottom simulating actual industrial parameters. The middle poplar veneer was coated with $125-150 \mathrm{~g} / \mathrm{m}^{2}$ resin on each side. Four pieces of three-layer plywood for each catalyst-accelerated resin (including control) were hot-pressed under 1.2 MPa at 100, 
110,120 , and $130{ }^{\circ} \mathrm{C}$, respectively. The hot-press time was $7 \mathrm{~min}$, including the first one minute and the last one minute to load and unload the pressure, respectively.

\subsection{Characterization of PF Resins}

The solid (non-volatile) content of resol resin was determined in accordance with ASTM standard D4426-01. The viscosity of resin was measured using a Brookfield DV-II viscometer (AMETEK-BROOKFIELD Corporation, Middleboro, MA, USA) using 61\# rotor with spinning rate of $100 \mathrm{rpm}$. Gel time was defined as the time period from the immersion of the test tube into the oil bath $\left(135^{\circ} \mathrm{C}\right)$ to the beginning of the resin gelation (resin forming a string when a glass rod was lifted from the resin).

\subsection{Characterization of the Plywood}

The shear strength was measured as per ASTM D906-98.

\subsection{FT-IR Analysis of PF Resins}

The resins were placed in $0.01 \mathrm{MPa}$ vacuum at $60^{\circ} \mathrm{C}$ for $4 \mathrm{~h}$ to dry to non-volatility. FT-IR spectra of vacuum-dried PF resins were performed in a Nicolet IS10 instrument (Thermo Fisher Scientific Corporation, Waltham, MA, USA). Each spectrum was recorded with 32 scans in a frequency range of $600-4000 \mathrm{~cm}^{-1}$ at a spectral resolution of $4 \mathrm{~cm}^{-1}$.

\subsection{Contact Angle Measurement}

The contact angle measurements of the PF resins were performed on the tangential surfaces of wood samples with an optical contact angle apparatus (OCA 20 DataPhysics Instruments GmnH, Filderstadt, Germany). Sessile droplets ( $3 \mu \mathrm{L}$, measured with a microsyringe) of liquid resin were placed on the wood surface. The right and left angles of the drops on the surface were collected at intervals of $0.1 \mathrm{~s}$ for a total duration of $60 \mathrm{~s}$, and the average angle was calculated.

\subsection{Quantitative Liquid ${ }^{13} \mathrm{C}$ NMR Measurement}

All of the resins were characterized by quantitative ${ }^{13} \mathrm{C}$ NMR spectroscopy with a VARIAN INOUR-300 (JEOL Corporation, Tokyo, Japan) spectrometer with a frequency of $75.51 \mathrm{MHz}$ using the inverse-gated decoupling method. All of the spectra were recorded at room temperature with a delay time of $8 \mathrm{~s}$, a $13 \mathrm{~h}$ acquisition time and a $15.4 \mu \mathrm{s}$ pulse width $\left(90^{\circ}\right)$. About $8000 \mathrm{scans}$ were accumulated to obtain spectra for each spectrum. The chemical shifts of each spectrum were accurate to $0.1 \mathrm{ppm}$ and all the resin samples were directly used for ${ }^{13} \mathrm{C}$ NMR measurement.

\subsection{Thermogravimetric Analysis (TG) of Resins}

Samples were dried at $120^{\circ} \mathrm{C}$ for $2 \mathrm{~h}$ to evaporate the moisture and then TG was performed in a nitrogen atmosphere within a temperature range from room temperature to $700{ }^{\circ} \mathrm{C}$, with a heating rate of $10{ }^{\circ} \mathrm{C} / \mathrm{min}$.

\section{Results and Discussion}

\subsection{Performance of the Catalyst-Accelerated PF Resin}

Table 1 shows the solid content, viscosity, and gel time of the PF resins. We found that the solid contents were similar for all resins, but the viscosity varied greatly for different catalysts. The viscosity of the $\mathrm{Na}_{2} \mathrm{CO}_{3}$-accelerated resin was $153.00 \mathrm{mPa} \cdot \mathrm{s}$, higher than the viscosity of the other catalyst-accelerated PF resins, especially the control resin with a low viscosity of $25.70 \mathrm{mPa} \cdot \mathrm{s}$. Similarly, the gel-time for the catalyst-accelerated resins varied from $11.83 \mathrm{~min}$ for the $\mathrm{Na}_{2} \mathrm{CO}_{3}$-accelerated resin to $20.46 \mathrm{~min}$ for the control resin. These results indicated that these catalysts were able to accelerate 
the synthesis reaction to different extents. The ability of the catalysts to accelerate the reactions could be ranked as $\mathrm{Na}_{2} \mathrm{CO}_{3}>\left(\mathrm{CH}_{3} \mathrm{COO}\right)_{2} \mathrm{Zn}>\mathrm{Ba}(\mathrm{OH})_{2}>\mathrm{LiOH}$. Under the same reaction conditions, the catalyst $\mathrm{Na}_{2} \mathrm{CO}_{3}$ can dramatically accelerate the synthesis reaction process, increase the viscosity, and decrease the gel time of PF resin.

Table 1. PF resin characteristics.

\begin{tabular}{cccc}
\hline \multirow{2}{*}{ Catalyst type } & \multicolumn{3}{c}{ Performance } \\
\cline { 2 - 4 } & Solid content (\%) & Viscosity (mPa·s) & Gel time (min) \\
\hline $\mathrm{Control}$ & 43 & 25.70 & 20.46 \\
$\mathrm{Ba}(\mathrm{OH})_{2}$ & 46 & 73.70 & 15.57 \\
$\mathrm{Na}_{2} \mathrm{CO}_{3}$ & 44 & 153.00 & 11.83 \\
$\mathrm{LiOH}$ & 46 & 58.30 & 15.88 \\
$\left(\mathrm{CH}_{3} \mathrm{COO}\right)_{2} \mathrm{Zn}$ & 44 & 81.00 & 13.98 \\
\hline
\end{tabular}

\subsection{Contact Angle of the PF Resins}

The wettability of PF resin on solid surface is usually evaluated by contact angle [13], which was tested on smoothed wood surface in this study. Due to liquid penetration and spreading on the wood surface, the contact angle changed as a function of time, as shown in Figure 1. The process of adhesive wetting includes three steps [14]: (1) formation of a contact angle at the solid and adhesive interface; (2) spreading of the adhesive over a solid surface; and (3) adhesive penetration into the porous solid substrate, as shown in Figure 2.

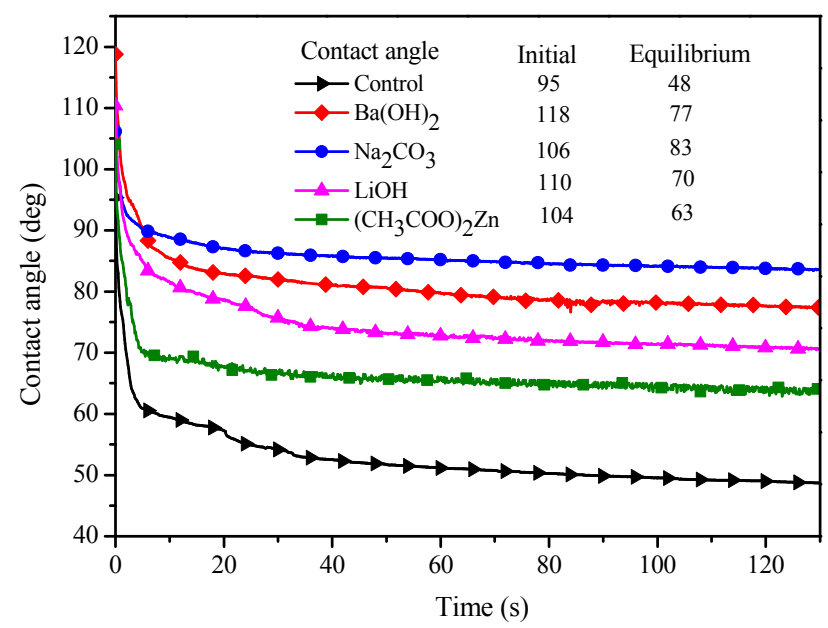

Figure 1. Contact angle as a function of time for the PF resins accelerated by different catalysts.
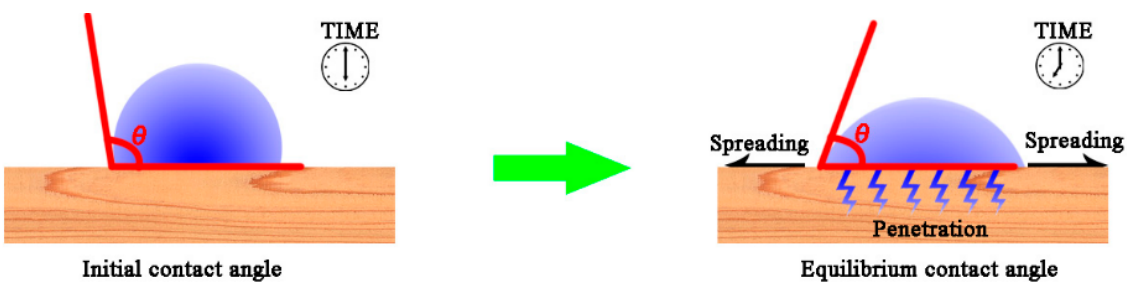

Equilibrium contact angle

Figure 2. Manifestation of adhesive wetting process: contact, spreading, and penetration.

As shown in Figure 1, at the initial stage of the wetting process, the contact angle of the resins decreased quickly. As time elapsed, the contact angle decreased more slowly and finally attained relative equilibrium. It was observed that the $\mathrm{Na}_{2} \mathrm{CO}_{3}$-accelerated $\mathrm{PF}$ resin showed the 
largest equilibrium contact angle, and the resins could be ranked as $\mathrm{Na}_{2} \mathrm{CO}_{3}>\mathrm{Ba}(\mathrm{OH})_{2}>\mathrm{LiOH}$ $>\left(\mathrm{CH}_{3} \mathrm{COO}\right)_{2} \mathrm{Zn}>$ Control. The results suggested that the $\mathrm{Na}_{2} \mathrm{CO}_{3}$-accelerated $\mathrm{PF}$ resin had the largest surface tension, which may be due to its larger viscosity. Figure 1 also shows that the $\left(\mathrm{CH}_{3} \mathrm{COO}\right)_{2} \mathrm{Zn}$-accelerated resin had the fastest rate of contact angle change, which meant that $\left(\mathrm{CH}_{3} \mathrm{COO}\right)_{2} \mathrm{Zn}$-accelerated resin could spread and penetrate more quickly into the porous structure of wood. Both viscosity and the chemical constitution of PF resin could alter the contact angle change rate. Usually, samples with lower viscosity exhibit a faster contact angle change rate. However, from the data in Table 1, $\left(\mathrm{CH}_{3} \mathrm{COO}\right)_{2} \mathrm{Zn}$-accelerated resin showed higher viscosity than that of the control sample, but had a faster contact angle change rate. Thus, the chemical constitution of $\left(\mathrm{CH}_{3} \mathrm{COO}\right)_{2} \mathrm{Zn}$-accelerated PF resin may be the main factor altering its contact angle change rate. The hydroxymethyl of PF resin is the main chemical group that can easily connect with the hydroxyl of wood cellulose; thus, our data suggests that $\left(\mathrm{CH}_{3} \mathrm{COO}\right)_{2} \mathrm{Zn}$-accelerated $\mathrm{PF}$ resin may contain more hydroxymethyl.

\subsection{FT-IR Spectroscopy}

To investigate the structural changes in the PF resins accelerated by different catalysts, FT-IR spectra (Figure 3) were obtained after vacuum-drying the samples. The spectra assignments of the PF resins are shown in Table 2 [15-17].

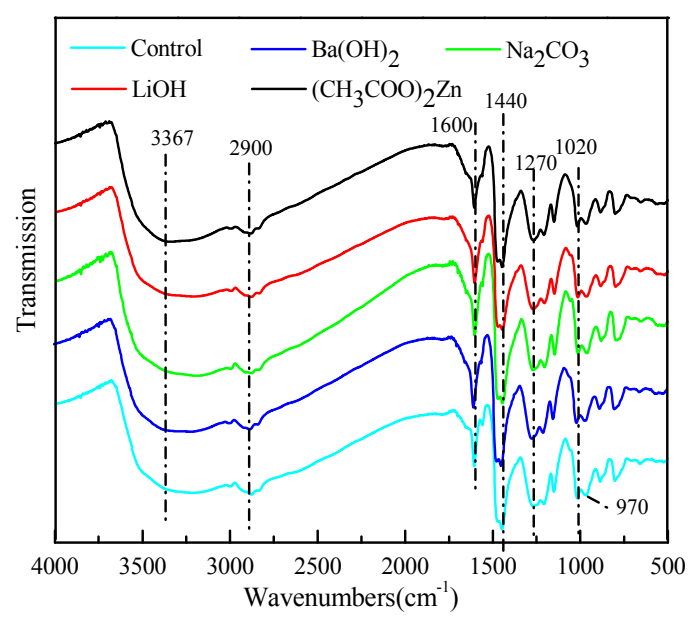

Figure 3. FT-IR spectra of the PF resins.

Table 2. Assignments of FT-IR spectra of the PF resin.

\begin{tabular}{cc}
\hline Wavenumbers $\left(\mathbf{c m}^{-\mathbf{1}}\right)$ & Assignment \\
\hline 3,367 & $-\mathrm{OH}$ stretching vibration \\
2,900 & $\mathrm{C}-\mathrm{H}$ stretching vibration of methylene \\
$1,600,1440$ & The elongation of aromatic $-\mathrm{C}=\mathrm{C}-$ \\
1,270 & $\mathrm{C}-\mathrm{O}$ stretching vibration of phenolic $\mathrm{C}-\mathrm{OH}$ and phenolic $\mathrm{C}-\mathrm{O}$ \\
1,020 & $\mathrm{C}-\mathrm{O}$ stretching vibration of aliphatic $\mathrm{C}-\mathrm{OH}$, aliphatic $\mathrm{C}-\mathrm{O}$, and methylol $\mathrm{C}-\mathrm{OH}$ \\
970 & $\mathrm{C}-\mathrm{H}$ stretching vibration of vinyl \\
\hline
\end{tabular}

There were no significant differences between the spectra of the catalyst-accelerated resins and the control sample, which indicated structural similarity. Bands at $1020 \mathrm{~cm}^{-1}$ were ascribed to $\mathrm{C}-\mathrm{O}$ stretching vibration of aliphatic $\mathrm{C}-\mathrm{OH}$, aliphatic $\mathrm{C}-\mathrm{O}$, and methylol $\mathrm{C}-\mathrm{OH}$. Bands at $1600 \mathrm{~cm}^{-1}$ were assigned to the elongation of aromatic $-\mathrm{C}=\mathrm{C}-$, which were consistent in each reaction system and unaffected by catalyst reaction. Thus, bands at $1600 \mathrm{~cm}^{-1}$ could be used as an internal standard for analysis. The ratio of absorption value of $1020 \mathrm{~cm}^{-1}$ (variable) $/ 1600 \mathrm{~cm}^{-1}$ (constant) was calculated to indicate the degree of hydroxymethyl for phenol in each catalyst accelerated-reaction system, as shown in Table 3. The control of PF resins had a relatively larger ratio of $1020 \mathrm{~cm}^{-1} / 1600 \mathrm{~cm}^{-1}$, which may 
be explained by the fact that the methylol of catalyst-accelerated PF resin tends to undergo further condensation reactions to form methylene $\left(-\mathrm{CH}_{2}-\right)$. Thus, the control sample had relatively more unreacted methylol. This explanation was confirmed by the fact that the control sample showed the lowest viscosity due to its relatively minimum condensation degree.

Table 3. The ratio of absorption value of $1020 \mathrm{~cm}^{-1}$ (variable) $/ 1600 \mathrm{~cm}^{-1}$ (constant) of the PF resins with different catalysts.

\begin{tabular}{cccccc}
\hline \multirow{2}{*}{ Wavenumbers $\left(\mathbf{c m}^{-\mathbf{1}}\right)$} & \multicolumn{5}{c}{ Absorption } \\
\cline { 2 - 6 } & Control & $\mathbf{B a}(\mathbf{O H})_{\mathbf{2}}$ & $\mathbf{N a}_{\mathbf{2}} \mathbf{C O}_{\mathbf{3}}$ & $\mathbf{L i O H}$ & $\left.\mathbf{( C H}_{\mathbf{3}} \mathbf{C O O}\right)_{\mathbf{2}} \mathbf{Z n}$ \\
\hline 1,020 & 43.46 & 32.63 & 33.79 & 45.43 & 29.85 \\
1,600 & 29.75 & 28.14 & 29.94 & 38.54 & 24.81 \\
Ratio $(1,020 / 1,600)$ & 1.46 & 1.16 & 1.13 & 1.17 & 1.20 \\
\hline
\end{tabular}

\subsection{Chemical Structure Analysis}

In order to identify the effect of different catalysts on the functional groups, quantitative ${ }^{13} \mathrm{C} N \mathrm{NR}$ was used to study the difference of chemical shifts between the control and catalyst-accelerated PF resins. The ${ }^{13} \mathrm{C}$ NMR spectra are shown in Figure 4, and their corresponding assignments of groups' signals are shown in Figure 5 [12,18-20].

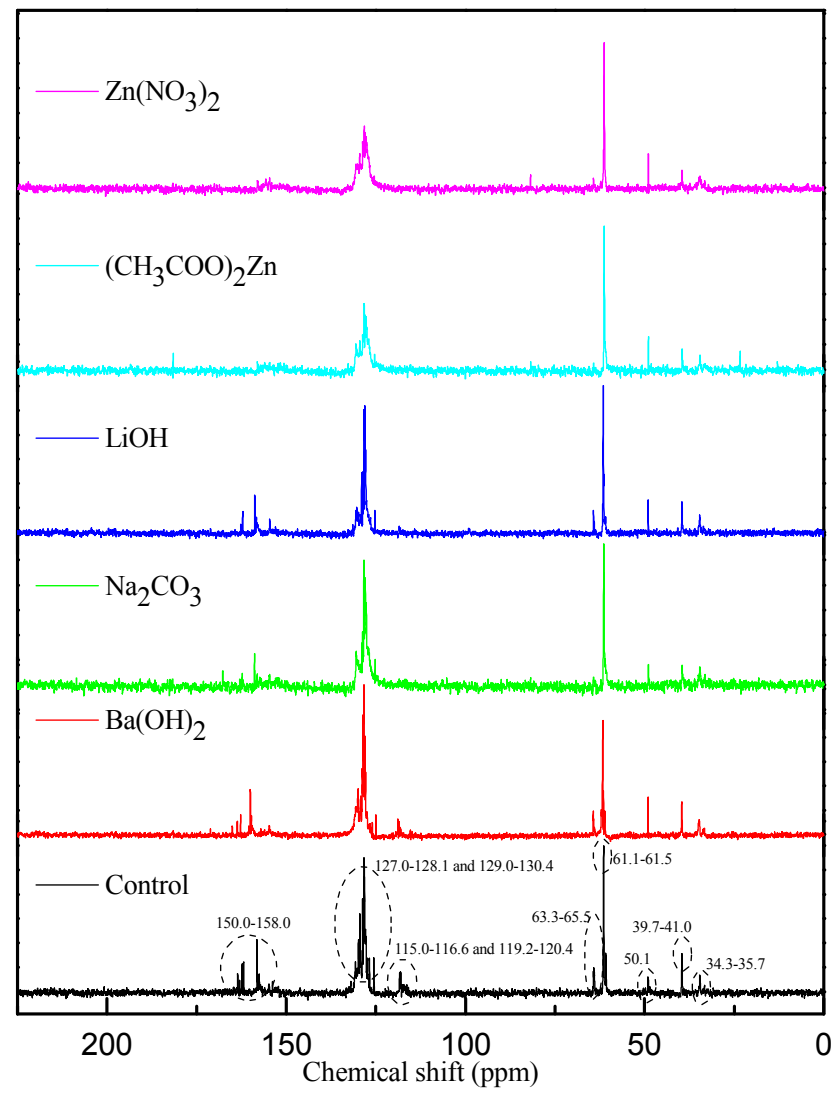

Figure 4. Liquid ${ }^{13} \mathrm{C}$ NMR spectra of PF resins. 


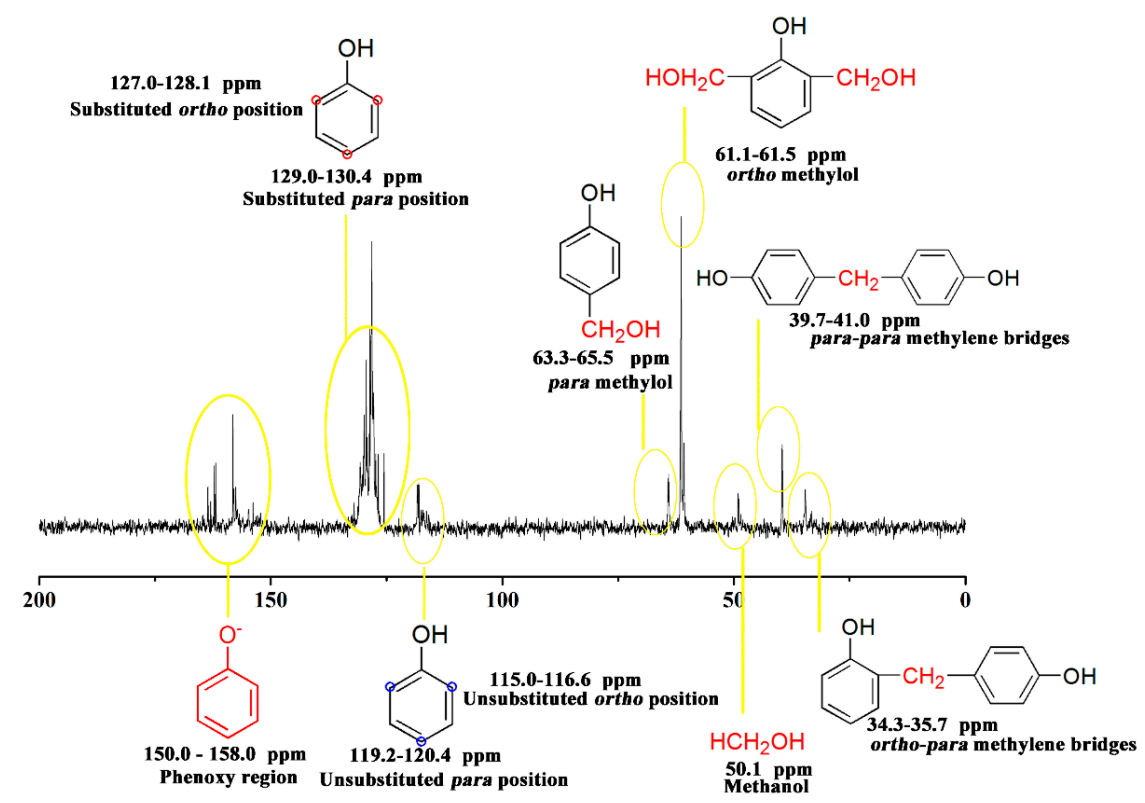

Figure 5. Liquid ${ }^{13} \mathrm{C}$ NMR chemical shifts and group assignments of PF resin.

The chemical shift of 150.0-158.0 ppm was assigned to phenoxy carbons $(\mathrm{C} 1-\mathrm{OH})$, which was used as an integral standard and analytical standpoint. 156.2-156.8 ppm and 153.4-156.1 ppm were assigned to para alkylated groups and ortho alkylated groups, respectively. Usually, phenolic ortho and para carbons' chemical shifts vary with the sodium hydroxide contents of the resin due to the ionization of phenoxy group and the kind of substituted groups. Substitution with methylol groups in the para and ortho carbon positions was shown at 129.0-130.4 ppm and 127.0-128.1 ppm. Unsubstituted para and ortho carbons, the main reactive sites for the methylolation reaction, occurred at 119.2-120.4 ppm and 115.0-116.6 ppm, respectively. The unsubstituted para and ortho carbon peaks were only present in the control and $\mathrm{Ba}(\mathrm{OH})_{2}$-accelerated $\mathrm{PF}$ resins, which indicated that $\mathrm{Na}_{2} \mathrm{CO}_{3}, \mathrm{LiOH}$, and $\left(\mathrm{CH}_{3} \mathrm{COO}\right)_{2} \mathrm{Zn}$ facilitate the reaction of formaldehyde with phenolic ortho and para position more than what occurs in the control and $\mathrm{Ba}(\mathrm{OH})_{2}$ samples. A sharp peak of methanol was evident around $50 \mathrm{ppm}$ for all resins. Industrial formaldehyde usually contains a small amount of methanol which can also be formed during resin synthesis from the Canizzaro reaction of formaldehyde. The signal peak of methylol is sharper than the methylene peak due to its higher group mobility and less variation in the environment within the polymer structure. Thus, the two peaks at 63.3-65.5 ppm and 61.1-61.5 ppm were assigned to para methylol and ortho methylol. Theoretically, condensation between two methylols can occur to form methylene ether bridges. However, the data in Figure 4 shows no peak between 69 and $74 \mathrm{ppm}$, indicating that methylene ether bridges were not formed between phenolic units during the synthesis of PF resin. The methylene bridges were easily observed in the range of 34-41 ppm. In a different chemical environment, different methylene linkages showed a different chemical shift, 39.7-41.0 ppm and 34.3-35.7 ppm were assigned to para-para and ortho-para methylene bridges, respectively. In order to remove the interference of carbon in $\mathrm{CH}_{3} \mathrm{COO}^{-}$for ${ }^{13} \mathrm{C}$ NMR analysis, the $\mathrm{Zn}\left(\mathrm{NO}_{3}\right)_{2}$-accelerated resin was also tested by ${ }^{13} \mathrm{C}$ NMR analysis and used as a control for the ${ }^{13} \mathrm{C}$ NMR analysis of $\left(\mathrm{CH}_{3} \mathrm{COO}\right)_{2} \mathrm{Zn}$-accelerated resin.

Further analysis of quantitative ${ }^{13} \mathrm{C}$ NMR is needed to elucidate the details of the cure-acceleration effect of different catalysts on the structure and compositions of PF resin. In this study, the ratios of integral values of the substituted position ortho (127.0-128.1 ppm)/para (129.0-130.4 ppm), ortho methylol (61.1-61.5 ppm)/para methylol (63.3-65.5 ppm), and methylene bridges ortho-para (34.3-35.7 ppm)/ para-para (39.7-41.0 ppm) were calculated, as shown in Table 4. PF resins supplemented with $\mathrm{Na}_{2} \mathrm{CO}_{3}, \mathrm{LiOH}$, and especially $\left(\mathrm{CH}_{3} \mathrm{COO}\right)_{2} \mathrm{Zn}$, possessed higher ratios of ortho/para-substituted positions than did the control or the PF resin with $\mathrm{Ba}(\mathrm{OH})_{2}$. In case of the ortho/para ratio of methylol, 
the values of $\mathrm{Na}_{2} \mathrm{CO}_{3}$-accelerated and $\left(\mathrm{CH}_{3} \mathrm{COO}\right)_{2} \mathrm{Zn}$-accelerated PF resins were not calculated (NC), because their ${ }^{13} \mathrm{C}$ NMR spectra showed no signal for para methylol. Either $\mathrm{Na}_{2} \mathrm{CO}_{3}$ and $\left(\mathrm{CH}_{3} \mathrm{COO}\right)_{2} \mathrm{Zn}$ promoted the complete para methylol condensation reaction or drive formaldehyde toward the phenol ortho position exclusively. The ratio of ortho methylol/para methylol for the $\mathrm{Zn}\left(\mathrm{NO}_{3}\right)_{2}$-accelerated resin was much higher than other samples, excluding the $\mathrm{Na}_{2} \mathrm{CO}_{3}$-accelerated and $\left(\mathrm{CH}_{3} \mathrm{COO}\right)_{2} \mathrm{Zn}$-accelerated PF resins. Usually, para methylol groups react more easily with other para positions to form para-para linkages. However, the data in Table 5 indicates that ortho-para linkages were equal to para-para linkages in the $\mathrm{Na}_{2} \mathrm{CO}_{3}$-accelerated, $\mathrm{Zn}\left(\mathrm{NO}_{3}\right)_{2}$-accelerated, and $\left(\mathrm{CH}_{3} \mathrm{COO}\right)_{2} \mathrm{Zn}$-accelerated $\mathrm{PF}$ resins, suggesting that $\mathrm{Na}_{2} \mathrm{CO}_{3}, \mathrm{Zn}\left(\mathrm{NO}_{3}\right)_{2}$, and $\left(\mathrm{CH}_{3} \mathrm{COO}\right)_{2} \mathrm{Zn}$ were able to promote the condensation reaction to form ortho-para linkages. These results could be further proved by Table 1 that $\mathrm{Na}_{2} \mathrm{CO}_{3}$ and $\mathrm{Zn}\left(\mathrm{NO}_{3}\right)_{2}$-accelerated $\mathrm{PF}$ resins had higher viscosity, indicating that the significant promotion of phenol ortho position reactivity made $\mathrm{Na}_{2} \mathrm{CO}_{3}$ and $\mathrm{Zn}\left(\mathrm{NO}_{3}\right)_{2}$-accelerated PF resins have a tighter final network.

Table 4. Liquid ${ }^{13} \mathrm{C}$ NMR analysis results of PF resin formed with different catalysts.

\begin{tabular}{|c|c|c|c|}
\hline PF resin & $\begin{array}{c}\text { ortho/para } \\
\text { (Substituted position) }\end{array}$ & ortholpara (Methylol) & $\begin{array}{l}\text { ortho-para/para-para } \\
\text { (Methylene bridges) }\end{array}$ \\
\hline & & ${ }_{2} \mathrm{OH}$ & \\
\hline $\begin{array}{c}\text { Control } \\
\mathrm{Ba}(\mathrm{OH})_{2} \\
\mathrm{Na}_{2} \mathrm{CO}_{3} \\
\mathrm{LiOH} \\
\left(\mathrm{CH}_{3} \mathrm{COO}\right)_{2} \mathrm{Zn} \\
\mathrm{Zn}\left(\mathrm{NO}_{3}\right)_{2}\end{array}$ & $81^{0.288}$ & 5.171. & ${ }_{0.846}^{1}{ }^{1}$ \\
\hline
\end{tabular}

Table 5. Thermal properties of the cured PF resins.

\begin{tabular}{ccccccc}
\hline \multirow{2}{*}{ Catalyst type } & \multicolumn{5}{c}{$\boldsymbol{T}_{\max }$ of Thermal event $\left({ }^{\circ} \mathbf{C}\right)$} & \multirow{2}{*}{ Weight residue (\%) at $\mathbf{7 0 0}{ }^{\circ} \mathbf{C}$} \\
\cline { 2 - 5 } & First & Second & Third & Fourth & Fifth & \\
\hline Control & 155 & 260 & 394 & 507 & - & 65.5 \\
$\mathrm{Ba}(\mathrm{OH})_{2}$ & 156 & 262 & 390 & 503 & - & 68.0 \\
$\mathrm{Na}_{2} \mathrm{CO}_{3}$ & 153 & 300 & 386 & 512 & - & 65.5 \\
$\mathrm{LiOH}$ & 158 & 283 & 381 & 497 & - & 68.0 \\
$\left(\mathrm{CH}_{3} \mathrm{COO}\right)_{2} \mathrm{Zn}$ & 155 & 273 & 381 & 493 & 518 & 68.0 \\
\hline
\end{tabular}

In conclusion, all the catalysts tested showed accelerating effect to promote phenol ortho reactivity. However, $\left(\mathrm{CH}_{3} \mathrm{COO}\right)_{2} \mathrm{Zn}$ and $\mathrm{Na}_{2} \mathrm{CO}_{3}$ were able to significantly promote the reaction activity of phenol ortho position and the condensation reaction of ortho methylol or directed formaldehyde exclusively toward the phenol ortho position.

\subsection{Plywood Performance}

Figure 6 shows the bonding strength of the plywood prepared with these different PF resins. Each kind of plywood was prepared at four hot-pressing temperatures, namely 100, 110, 120, and $130{ }^{\circ} \mathrm{C}$. Higher hot-pressed temperatures allowed the resin to cure more completely and, thus, increase the bonding strength. Under the same hot-pressing temperature, the plywood prepared with catalyst-accelerated PF resins exhibited higher bonding strength than the control sample, especially the one with $\mathrm{Na}_{2} \mathrm{CO}_{3}$-accelerated PF resin. The data in Figure 6 shows that the plywood prepared 
with $\mathrm{Na}_{2} \mathrm{CO}_{3}$-accelerated resin at $110^{\circ} \mathrm{C}$ yielded almost the same bonding strength of plywood with $\mathrm{Ba}(\mathrm{OH})_{2}$-accelerated resin at $120^{\circ} \mathrm{C}$, which is higher than that of the control sample pressed at $120^{\circ} \mathrm{C}$. The reason may be that the $\mathrm{Na}_{2} \mathrm{CO}_{3}$-accelerated $\mathrm{PF}$ resin had the highest viscosity among PF resins from Table 1, or that $\mathrm{Na}_{2} \mathrm{CO}_{3}$ significantly improved $\mathrm{PF}$ resin performance by promoting the reaction activity of phenol ortho position.

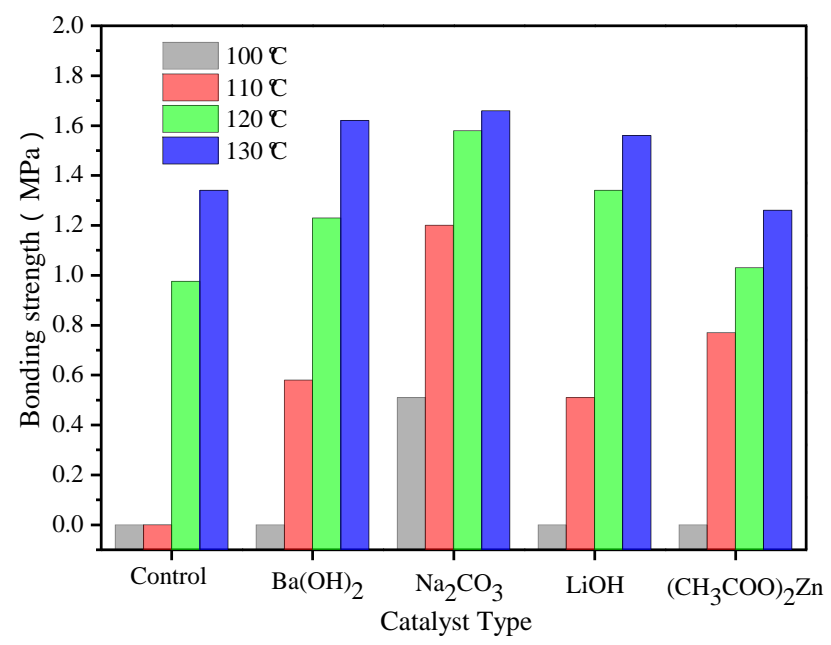

Figure 6. Effect of catalysts at different temperatures on the bonding strength.

\subsection{Thermal Behavior of the Cured PF Resins}

To characterize the thermal stability of the catalyst-accelerated PF resins, TG analysis was performed next, as shown in Figure 7. The temperatures at which the maximum degradation speed took place $\left(T_{\max }\right)$ for the different thermal events of cured catalyst-accelerated PF resins are shown in Table 5.

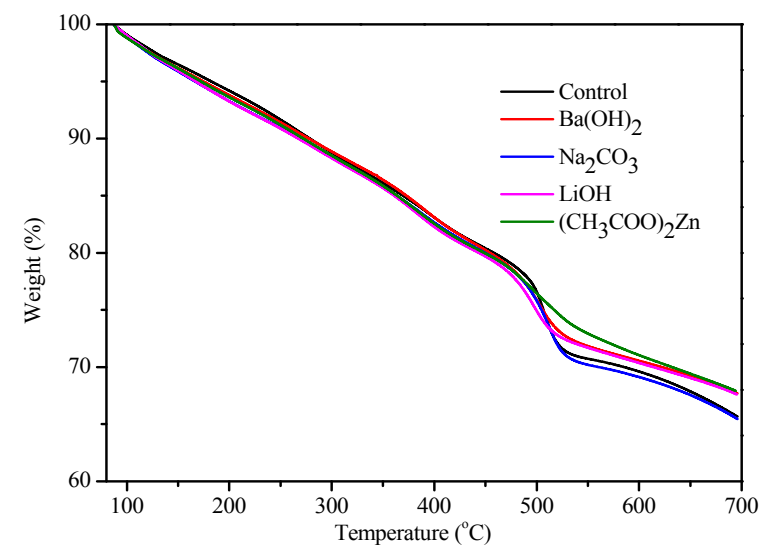

(a)

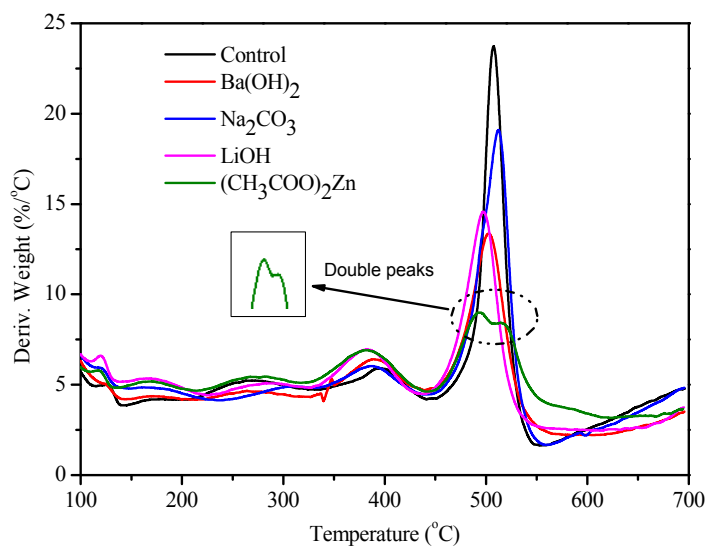

(b)

Figure 7. TG (a) and DTG (b) curves of the cured PF resins.

It was previously known that phenolic resin degrades in three steps: post-curing, thermal reforming, and ring stripping [21,22]. The mass loss (about 5\%) of the first thermal event at the lower temperature range $\left(<155^{\circ} \mathrm{C}\right)$ contributed to the evaporation of free water. In the second stage, with a temperature range from 230 to $300^{\circ} \mathrm{C}$, mass loss was due to the evaporation of water formed by the condensation reaction of methylol groups. The mass loss in the third event (from 350 to $440{ }^{\circ} \mathrm{C}$ ) was due to the loss of water formed by the condensation reaction of methylol and phenolic hydrogen, as well as between two hydroxyl functional groups, which could cause further structure change of the 
cured products to a more tightly cross-linked network. In the fourth event $\left(>450^{\circ} \mathrm{C}\right)$, the mass loss was due to the loss of carbon monoxide and methane formed by degradation of the methylene linkage. As the temperature further increased, the remaining mass was from $65 \%$ to $68 \%$ at $700{ }^{\circ} \mathrm{C}$, and that of $\mathrm{Ba}(\mathrm{OH})_{2}, \mathrm{Na}_{2} \mathrm{CO}_{3}$, and $\left(\mathrm{CH}_{3} \mathrm{COO}\right)_{2} \mathrm{Zn}$-accelerated $\mathrm{PF}$ resins was higher than other samples, indicating that a tighter network and higher thermal stability was possessed by their molecular structure.

Figure 7 shows TG (a) and DTG (b) curves of the catalyst-accelerated PF resins. All of the PF resins showed similar thermal stability in the first three stages of thermal events. However, in the final event, the DTG curve of the $\left(\mathrm{CH}_{3} \mathrm{COO}\right)_{2} \mathrm{Zn}$-accelerated resin showed lower degradation speed than the other PF resins, and had double peaks of degradation speed. According to Pizzi and Mohamed et al. [23-25], when a benzene ring was blended with a zinc ion, a complex compound between the phenolic nuclei and the zinc ion could be formed by a metal-ligand mode, which can accelerate the initial reaction of formaldehyde toward the phenolic nuclei by forming a carbocation of strong positive charge. As shown in Scheme 1, the mobility of the polymer chain was restricted by ion-polymer and ion-interaction, resulting in a higher thermal stability of PF resin than the control sample. Thus, the first of double peaks at $493{ }^{\circ} \mathrm{C}$ may indicate the breakage of the metal-ligand bonding mode, and the second peak of the double peaks at $518^{\circ} \mathrm{C}$ may indicate the degradation of the methylene linkage.
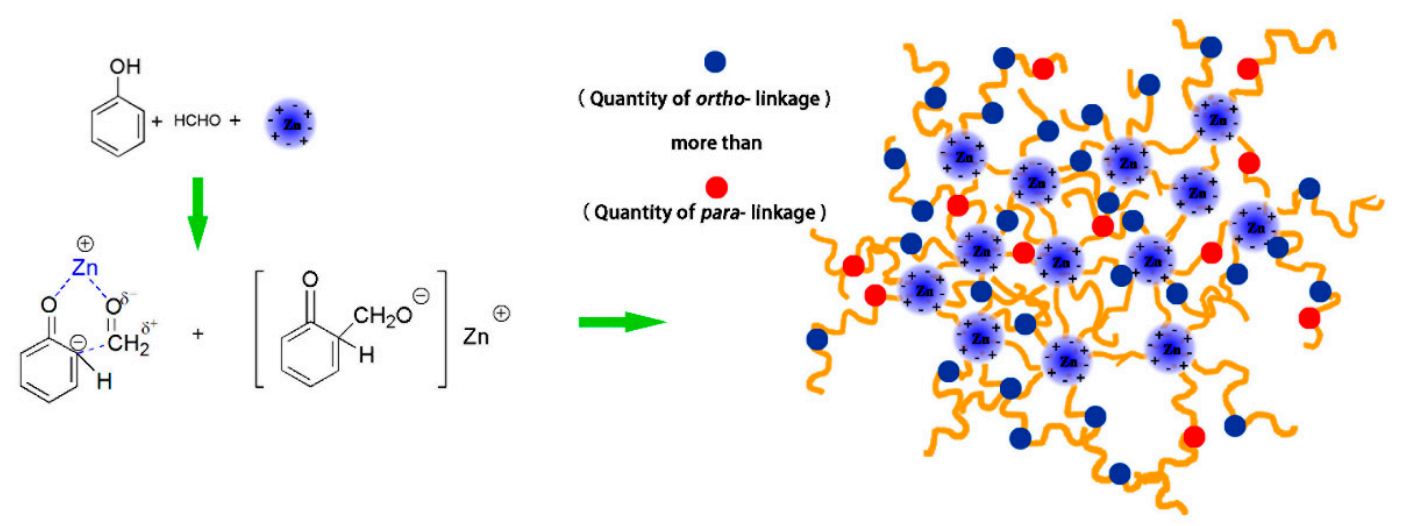

Scheme 1. Possible synthesis mechanism and metal-ligand coordination morphology of the $\left(\mathrm{CH}_{3} \mathrm{COO}\right)_{2} \mathrm{Zn} / \mathrm{PF}$ resin complex.

\section{Conclusions}

The poly-condensations of PF resins with different catalysts suggested different abilities to accelerate the reaction. In general, the accelerating efficiency of the catalysts was $\mathrm{Na}_{2} \mathrm{CO}_{3}>$ $\left(\mathrm{CH}_{3} \mathrm{COO}\right)_{2} \mathrm{Zn}>\mathrm{Ba}(\mathrm{OH})_{2}>\mathrm{LiOH}$.

The addition of $\mathrm{Na}_{2} \mathrm{CO}_{3}$ had a remarkable influence on the performance of PF resin. The viscosity of $\mathrm{Na}_{2} \mathrm{CO}_{3}$-accelerated PF resin increased to around $153 \mathrm{mPa} \cdot \mathrm{s}$ quickly, five-fold greater than the viscosity of the control resin. Moreover, the gel time of PF resin decreased significantly and the bonding strength of plywood increased by the addition of $\mathrm{Na}_{2} \mathrm{CO}_{3}$. The quantitative ${ }^{13} \mathrm{C}$ NMR analysis showed that the $\left(\mathrm{CH}_{3} \mathrm{COO}\right)_{2} \mathrm{Zn}$ and $\mathrm{Na}_{2} \mathrm{CO}_{3}$ catalysts could significantly promote the reaction activity of the phenol ortho position, and favor the condensation reaction of ortho methylol or direct formaldehyde toward the phenol ortho position exclusively. Compared with $\mathrm{Na}_{2} \mathrm{CO}_{3}$, the catalyst $\left(\mathrm{CH}_{3} \mathrm{COO}\right)_{2} \mathrm{Zn}$ showed a slightly weaker accelerating effect, but the contact angle analysis found that the $\left(\mathrm{CH}_{3} \mathrm{COO}\right)_{2} \mathrm{Zn}$-accelerated resin showed a faster contact angle change rate, which represents a better wettability on the wood surface. Furthermore, the different peaks in the DTG curve and higher weight residue of TG data indicated that $\left(\mathrm{CH}_{3} \mathrm{COO}\right)_{2} \mathrm{Zn}$ has a different accelerating mechanism to improve the thermal stability of PF resin. That mechanism may include metal-ligand bonding between the benzene ring and zinc ion formed by ion-polymer and ion-interaction.

In conclusion, catalysts such as $\mathrm{Na}_{2} \mathrm{CO}_{3}$ and $\left(\mathrm{CH}_{3} \mathrm{COO}\right)_{2} \mathrm{Zn}$ showed significant accelerating effects to promote the curing of PF resin at lower temperatures and to improve PF resin performance. 
Thus, good catalyst-accelerated PF resins have promised to overcome the shortcoming of high curing temperature and to broaden their application.

Acknowledgments: This work was supported by the Chinese National Science and Technology Support Program (2015BAD14B03), the Special Fund for Forestry Research in the Public Interest (Project 201504502), and China Postdoctoral Science Foundation Funded Project (2015M570039).

Author Contributions: Zhao Yi contributed to synthesis, test, data analysis, and wrote manuscript. Jizhi Zhang, Jianzhang Li and Wei Zhang suggested and supervised the work and revised the manuscript. Shifeng Zhang, and Qiang Gao provided constructive suggestions about this work.

Conflicts of Interest: The authors declare no conflict of interest.

\section{References}

1. Hirano, K.; Asami, M. Phenolic resins-100 years of progress and their future. React. Funct. Polym. 2013, 73, 256-269. [CrossRef]

2. Nair, C.P.R. Advances in addition-cure phenolic resins. Prog. Polym. Sci. 2004, 29, 401-498. [CrossRef]

3. Lei, Y.; Wu, Q.; Lian, K. Cure kinetics of aqueous phenol-formaldehyde resins used for oriented strandboard manufacturing: Analytical technique. J. Appl. Polym. Sci. 2006, 100, 1642-1650. [CrossRef]

4. Zhao, C.; Pizzi, A.; Garnier, S. Fast advancement and hardening acceleration of low-condensation alkaline PF resins by esters and copolymerized urea. J. Appl. Polym. Sci. 1999, 74, 359-378. [CrossRef]

5. Lei, H.; Pizzi, A.; Despres, A.; Pasch, H.; Du, G. Ester acceleration mechanisms in phenol-Formaldehyde resin adhesives. J. Appl. Polym. Sci. 2006, 100, 3075-3093. [CrossRef]

6. Pizzi, A.; Stephanou, A. Completion of alkaline cure acceleration of phenol-formaldehyde resins: Acceleration by organic anhydrides. J. Appl. Polym. Sci. 1994, 51, 1351-1352. [CrossRef]

7. Gabilondo, N.; Lopez, M.; Ramos, J.A.; Echeverria, J.M.; Mondragon, I. Curing kinetics of amine and sodium hydroxide catalyzed phenol-formaldehyde resins. J. Therm. Anal. Calorim. 2007, 90, 229-236. [CrossRef]

8. Park, B.-D.; Riedl, B.; Hsu, E.W.; Shields, J. Differential scanning calorimetry of phenol-formaldehyde resins cure-accelerated by carbonates. Polymer 1999, 40, 1689-1699. [CrossRef]

9. Grenier-Loustalot, M.-F.; Larroque, S.; Grande, D.; Grenier, P.; Bedel, D. Phenolic resins: 2. Influence of catalyst type on reaction mechanisms and kinetics. Polymer 1996, 37, 1363-1369. [CrossRef]

10. Pizzi, A.; Garcia, R.; Wang, S. On the networking mechanisms of additives-accelerated phenol-formaldehyde polycondensates. J. Appl. Polym. Sci. 1997, 66, 255-266. [CrossRef]

11. Paju, J.; Pehk, T.; Christjanson, P. Structure of phenol-formaldehyde polycondensates. Proc. Estonian Acad. Sci. 2009, 58, 45-52. [CrossRef]

12. He, G.B.; Yan, N. ${ }^{13} \mathrm{C}$ NMR study on structure, composition and curing behavior of phenol-ureaformaldehyde resole resins. Polymer 2004, 45, 6813-6822. [CrossRef]

13. Lee, Y.-K.; Kim, H.J.; Rafailovich, M.; Sokolov, J. Curing monitoring of phenolic resol resins via atomic force microscope and contact angle. Int. J. Adhes. Adhes. 2002, 22, 375-384. [CrossRef]

14. Shi, S.Q.; Gardner, D.J. Dynamic adhesive wettability of wood. Wood Fiber Sci. 2001, 33, 58-68.

15. Chu, P.P.; Reddy, M.J.; Tsai, J. Structural and transport characteristics of polyethylene oxide/phenolic resin blend solid polymer electrolytes. J. Polym. Sci. Part B Polym. Phys. 2004, 42, 3866-3875. [CrossRef]

16. Zhang, W.; Ma, Y.F.; Xu, Y.Z.; Wang, C.P.; Chu, F.X. Lignocellulosic ethanol residue-based lignin-phenolformaldehyde resin adhesive. Int. J. Adhes. Adhes. 2013, 40, 11-18. [CrossRef]

17. Lin, C.T.; Lee, H.T.; Chen, J.K. Preparation and properties of bisphenol-F based boron-phenolic resin/modified silicon nitride composites and their usage as binders for grinding wheels. Appl. Surf. Sci. 2015, 330, 1-9. [CrossRef]

18. Park, B.-D.; Riedl, B. ${ }^{13} \mathrm{C}-\mathrm{NMR}$ study on cure-accelerated phenol-formaldehyde resins with carbonates. J. Appl. Polym. Sci. 2000, 77, 1284-1293. [CrossRef]

19. Vázquez, G.; López-Suevos, F.; Villar-Garea, A.; González-Alvarez, J.; Antorrena, G. ${ }^{13}$ C-NMR analysis of phenol-urea-formaldehyde prepolymers and phenol-urea-formaldehyde-tannin adhesives. J. Adhes. Sci. Technol. 2004, 18, 1529-1543. [CrossRef]

20. Fan, D.; Chang, J.; Li, J.; Mao, A.; Zhang, L. ${ }^{13} \mathrm{C}-\mathrm{NMR}$ study on the structure of phenol-urea-formaldehyde resins prepared by methylolureas and phenol. J. Appl. Polym. Sci. 2009, 112, 2195-2202. [CrossRef] 
21. Alma, M.H.; Kelley, S.S. Thermal stability of novolak-type thermosettings made by the condensation of bark and phenol. Polym. Degrad. Stab. 2000, 68, 413-418. [CrossRef]

22. Yi, Z.; Li, C.; Jiang, J.X.; Zhang, J.Z.; Zhang, W.; Li, J.Z. Pyrolysis kinetics of tannin-phenol-formaldehyde resin by non-isothermal thermogravimetric analysis. J. Therm. Anal. Calorim. 2015, 121, 867-876. [CrossRef]

23. Mohamed, M.G.; Su, W.C.; Lin, Y.C.; Wang, C.F.; Chen, J.K.; Jeong, K.U.; Kuo, S.W. Azopyridinefunctionalized benzoxazine with $\left.\mathrm{Zn}\left(\mathrm{ClO}_{4}\right)_{2}\right)$ form high-performance polybenzoxazine stabilized through metal-ligand coordination. RSC Adv. 2014, 4, 50373-50385. [CrossRef]

24. Pizzi, A. Phenolic resins by reactions of coordinated metal ligands. J. Polym. Sci. Polym. Lett. Ed. 1979, 17, 489-492. [CrossRef]

25. Pizzi, A. Phenolic and tannin-based adhesive resins by reactions of coordinated metal ligands. I. Phenolic chelates. J. Appl. Polym. Sci. 1979, 24, 1247-1255. [CrossRef]

(C) 2016 by the authors; licensee MDPI, Basel, Switzerland. This article is an open access article distributed under the terms and conditions of the Creative Commons Attribution (CC-BY) license (http://creativecommons.org/licenses/by/4.0/). 